\title{
Disproportionation, Electrochemistry, and Electronic Coupling involving Mononuclear and Binuclear Cobalt Phthalocyanine Derivatives
}

\author{
Wei Liu, Michael R. Hempstead, W. Andrew Nevin, Milan Melník, Alfred B. P. Lever," and \\ Clifford C. Leznoff \\ Department of Chemistry, York University, North York, Toronto, Ontario, Canada M3J 1P3
}

Electronic spectroscopic data are reported for $\mathrm{Co}^{\prime}, \mathrm{Co}^{\prime \prime}$, and $\mathrm{Co}^{\prime \prime \prime}$ mononuclear tetra(neopentoxy) phthalocyaninate $(2-)\left(L^{1}\right)$ and bridged binuclear tri(neopentoxy) phthalocyaninate $(2-)$ species in solution and film phases. Electrochemical data show that the [Co "L'] species cannot exist in a non-co-ordinating or weakly co-ordinating solvent containing hydroxide ion. Such solutions cause disproportionation of [Co $\left.\mathrm{Co}^{\prime \prime} L^{\prime}\right]$ to a $1: 1$ mixture of $\left[\mathrm{Co}^{\prime} L^{\prime}\right]^{-}$and $\left[\mathrm{Co}^{\prime \prime \prime} \mathrm{L}^{1}\right]^{+}$(axial ligands omitted). The detailed electrochemistry of this system is explored. The chemistry of these two oxidation states towards heat, light, acids, bases, carbonate and sulphite ion are briefly reported for solution and film phases. The degree of intermolecular electronic coupling which occurs either through space, through the bridge, or directly in cofacial conformers is discussed in terms of the nature of the bridge of the binuclear species and oxidation state of the cobalt.

We have recently reported ${ }^{1-4}$ a series of binuclear substituted phthalocyaninate $(2-)(\mathrm{pc})$ complexes comprising two tri(neopentoxy)phthalocyaninate( $2-$ ) units joined by a bridge containing one, two, four, or five atoms. The three neopentoxy groups are randomly distributed in the 4- or 5-positions of the three unlinked benzene rings. They provide for solubility in organic solvents, but the presence of inseparable isomers precludes proper crystallisation and crystal structure analysis. The complexes reported in this paper are as follows. [Tetra(neopentoxy)phthalocyaninato]cobalt(ti), [Co $\left.\mathrm{Co}^{\mathrm{II}} \mathrm{L}^{1}\right]$, is the mononuclear control molecule. The binuclear complexes have two [tri(neopentoxy)phthalocyaninato( $2-)]$ cobalt(II) units linked by a (five-atom) $-\mathrm{OCH}_{2} \mathrm{C}(\mathrm{Et})(\mathrm{Me}) \mathrm{CH}_{2} \mathrm{O}-$ bridge, $\left[\mathrm{Co}^{11}{ }_{2} \mathrm{~L}^{2}\right] ;$ a (four-atom) catechol $-\mathrm{OC}_{6} \mathrm{H}_{4} \mathrm{O}$ - bridge, $\left[\mathrm{Co}_{2}{ }_{2} \mathrm{~L}^{3}\right]$; a (two-atom) $-\mathrm{CH}_{2} \mathrm{CH}_{2}$ bridge, $\left[\mathrm{Co}_{2}{ }_{2} \mathrm{~L}^{4}\right]$; or a (single-atom) ether $-\mathrm{O}-$ bridge, $\left[\mathrm{Co}^{11}{ }_{2} \mathrm{~L}^{\mathrm{s}}\right]$. The corresponding neutral, metal-free ligands are designated $\mathrm{H}_{2} \mathrm{~L}^{1}, \mathrm{H}_{4} \mathrm{~L}^{2}, \mathrm{H}_{4} \mathrm{~L}^{3}$, $\mathrm{H}_{4} \mathrm{~L}^{4}$, and $\mathrm{H}_{4} \mathrm{~L}^{5}$ respectively.

In discussing the metal-free derivatives, ${ }^{5}$ certain conclusions were drawn which are relevant to the present paper. (i) In condensed phases (frozen solution glass, crystal, Nujol mull, etc.), these complexes may exhibit intermolecular aggregation. In dilute solution $\left(<5 \times 10^{-5} \mathrm{~mol} \mathrm{\textrm {dm } ^ { - 3 } )}\right.$ intermolecular aggregation is generally absent. (ii) Some binuclear phthalocyanines may close in upon themselves ('clamshell' behaviour) via cofacial intramolecular aggregation. Specifically, of the metal-free group, only $\mathrm{H}_{4} \mathrm{~L}^{2}$ and $\mathrm{H}_{4} \mathrm{~L}^{3}$ are capable of such intramolecular cofacial aggregation. Such species exist in a dynamic equilibrium with 'open' conformations. (iii) The electronic spectra of the metal-free species show evidence of the coupling of the transition moments on each phthalocyanine ring expected to be more important here than in the porphyrins, because of the larger visible region transition moments of the former. ${ }^{6}$ In the cofacial conformations coupling gives rise to a blue shift in the $Q$ and Soret absorptions. A blue shift is also observed in the other metal-free binuclear species, as a consequence of coupling through space (or through the bridge) in 'open, non-aggregated conformations. (iv) Deprotonated binuclear phthalocyanine species show evidence for electronic coupling through space in the form of broadening or splitting of the $Q$-band absorption. ${ }^{5}$

Polynuclear complexes are of interest in the design of

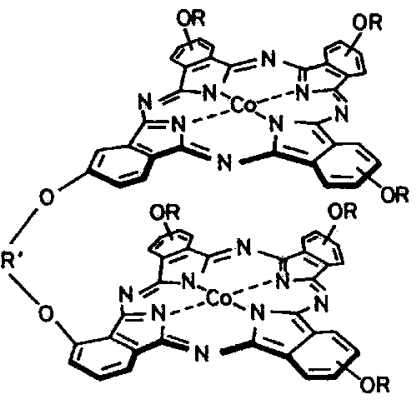

$\left[\mathrm{CO}_{2}{ }_{2} \mathrm{~L}^{2}\right] ; \quad \mathrm{R}=\mathrm{CH}_{2} \mathrm{CMe}_{3}, \mathrm{R}^{\prime}=\mathrm{CH}_{2} \mathrm{C}(\mathrm{Et})(\mathrm{Me}) \mathrm{CH}_{2}$ $\left[\mathrm{CO}_{2}^{\mathrm{II}} \mathrm{L}^{3}\right] ; \mathrm{R}=\mathrm{CH}_{2} \mathrm{CMe}_{3}, \mathrm{R}^{\prime}=0-\mathrm{C}_{6} \mathrm{H}_{4}$

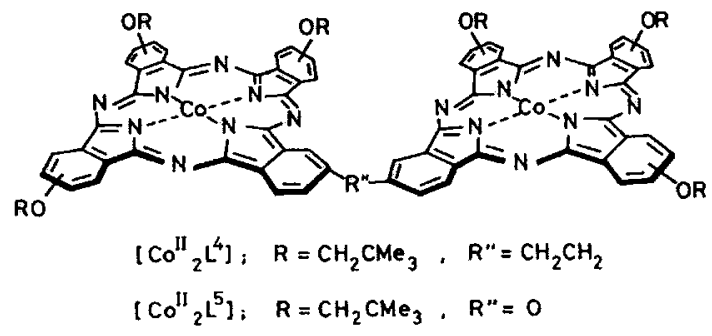

multi-electron photoredox and electroredox catalysts. Many important redox processes, especially the water-oxygen redox system, are multi-electron in nature and may be catalysed more effectively (higher quantum yield, greater catalytic efficiency) by redox catalysts which can participate in a concerted two (or more)-electron process with the substrate.

While polynuclear porphyrins, some of which are cofacial, have been the subject of investigation in recent years, ${ }^{7-9}$ these species are generally difficult to prepare, and are less stable chemically than phthalocyanine analogues are expected to be. Phthalocyanine complexes are effective in catalysing, for example, oxygen reduction at a cathode ${ }^{10.11}$ and it is especially 
relevant that dimeric and polymeric phthalocyanines, while rather poorly characterised, are more effective ${ }^{12-14}$ than their mononuclear analogues. Preliminary studies of these bridged binuclear [tri(neopentoxy)phthalocyaninato]cobalt(II) systems, ${ }^{15}$ deposited as monolayers on graphite electrodes and suspended in alkaline solution, do indeed show that they are oxygen-reduction electrocatalysts and that they are more efficient than the mononuclear control molecules.

In principle, one might design such a catalyst by arranging for example, that it be stable in two oxidation states separated by two electrons, with the intermediate oxidation state being thermodynamically unstable. Alternatively one might link two, one-electron catalysts together with strong coupling such that two-electron oxidation and reduction rather than sequential one-electron processes occur.

Both of these opportunities exist in the cobalt phthalocyanine system and we present here a discussion of the redox chemistry and electronic structure of mononuclear and binuclear cobalt phthalocyanine derivatives, together with associated electrochemical support

\section{Experimental}

The species $\left[\mathrm{Co}^{\mathrm{II}} \mathrm{L}^{1}\right],{ }^{1}\left[\mathrm{Co}^{\mathrm{II}}{ }_{2} \mathrm{~L}^{2}\right],{ }_{2}^{1}\left[\mathrm{Co}_{2}{ }_{2} \mathrm{~L}^{3}\right],{ }^{2}\left[\mathrm{Co}^{\mathrm{II}}{ }_{2} \mathrm{~L}^{4}\right]{ }^{2}$ and $\left[\mathrm{Co}^{\mathrm{II}}{ }_{2} \mathrm{~L}^{5}\right]^{3}$ were prepared as previously described. Tetrabutylammonium perchlorate (Kodak) was recrystallised from absolute ethanol and dried at $50^{\circ} \mathrm{C}$ under vacuum for $2 \mathrm{~d} .1,2$ Dichlorobenzene (Aldrich, Gold Label), toluene (Aldrich, Gold Label), $N N$-dimethylformamide (dmf) (Aldrich, anhydrous, Gold Label), tetrabutylammonium hydroxide $\left(1 \mathrm{~mol} \mathrm{dm}^{-3}\right.$ in methanol, Kodak), lithium hydroxide (J. T. Baker, Baker grade), polystyrene (Scientific Products), and poly(2-hydroxyethyl methacrylate) (phem) (Aldrich) were used as supplied. Al other chemicals used were analytical grade. Water was purified by double distillation over $\mathrm{KMnO}_{4}$ followed by passage through a Barnstead organic removal cartridge, and two Barnstead mixed-resin ultrapure cartridges.

Electronic spectra were recorded with a Hitachi-PerkinElmer Microprocessor 340 spectrometer or an AMINCO DW $2 \mathrm{~A}$ spectrometer. Electrochemical data were obtained with a Pine RDE3 double potentiostat or alternatively with a Princeton Applied Research (PARC) 173 potentiostat, or PARC 174A Polarographic Analyser coupled to a PARC 175 universal programmer. Cyclic and differential pulse voltammetry were carried out in a Vacuum Atmospheres Drilab under an atmosphere of nitrogen, on solutions which had been degassed by repeated freeze-pump-thaw cycles. A glassy carbon disc with an area of $0.458 \mathrm{~cm}^{2}$ served as a working electrode, a platinum wire as counter electrode, and a silver wire as quasireference electrode. Potentials were referenced internally to the ferrocenium-ferrocene couple. ${ }^{16}$ Controlled potential electrolysis was carried out with a gold minigrid in an optically transparent thin-layer electrode (o.t.t.l.e.) assembly which will be described elsewhere. ${ }^{17}$

Spectroelectrochemical measurements were made with a $\mathrm{C}_{6} \mathrm{H}_{4} \mathrm{Cl}_{2}$ solution containing ca. $5 \times 10^{-5} \mathrm{~mol} \mathrm{dm}^{-3}\left[\mathrm{CoL}^{1}\right]^{*}$ species and $0.3 \mathrm{~mol} \mathrm{dm}{ }^{-3} \mathrm{NBu}_{4} \mathrm{ClO}_{4}$ supporting electrolyte. Films of $\left[\mathrm{Co}^{11} \mathrm{~L}^{1}\right]$ in polymers were prepared in air by evaporation of solutions of the polymers in $\mathrm{C}_{6} \mathrm{H}_{4} \mathrm{Cl}_{2}$ or toluene, containing $\left[\mathrm{Co}^{11} \mathrm{~L}^{i}\right]$, while contacting borosilicate glass or quartz. Pure films were prepared by dissolving $\left[\mathrm{Co}^{\mathrm{II}} \mathrm{L}^{1}\right]$ in $\mathrm{C}_{6} \mathrm{H}_{4} \mathrm{Cl}_{2}$ or toluene and allowing the solvent to evaporate. For study under degassed conditions, the films were prepared

* The nomenclature $\left[\mathrm{CoL}^{1}\right]$ or $\left[\mathrm{Co}_{2} \mathrm{~L}^{n}\right](n=2-5)$ is used for a general species of undefined oxidation state. The $\mathrm{pc}(2-)$ state is the standard oxidation state for the phthalocyanine ring. by (diffusion) pumping off the solvent from the inside surface of a quartz cuvette. The cuvette was attached to a degassable cell such that degassed solutions (prepared by freeze-pump-thaw cycles) could be contacted with the film on the quartz surface, without breaking the vacuum seal. Films containing disproportionated $\left[\mathrm{Co}^{\prime} \mathrm{L}^{1}\right]^{-}-\left[\mathrm{Co}^{\mathrm{II}} \mathrm{L}^{\mathrm{t}}\right]^{+}$mixed species were obtained by adding excess $\mathrm{NBu}{ }_{4} \mathrm{OH}$ to the polymer-[Co $\left.\mathrm{Co}^{\mathrm{II}} \mathrm{L}^{1}\right]$ or $\left[\mathrm{Co}^{11} \mathrm{~L}^{1}\right]$ solution prior to evaporation.

\section{Results and Discussion}

Disproportionation in the Presence of Hydroxide Ion.-When hydroxide ion is added to $\mathrm{aC}_{6} \mathrm{H}_{4} \mathrm{Cl}_{2}$ solution of $\left[\mathrm{Co}^{\text {"l }} \mathrm{L}^{1}\right]$ under an inert (nitrogen) atmosphere, the solution is converted within the time of mixing to a $1: 1$ mixture of $\left[\mathrm{Co}^{1} \mathrm{~L}^{1}\right]^{-}$and $\left[\mathrm{Co}^{\mathrm{III}} \mathrm{L}^{1}\right]^{+}$, as indicated unequivocally by the resulting electronic spectrum [Figure $1(a)]{ }^{18-22}$ The $\left[\mathrm{Co}^{1} \mathrm{~L}^{1}\right]^{-}$species is typified by a $Q$ band near $710 \mathrm{~nm}$ and a metal to ligand charge-transfer (m.l.c.t) band near $470 \mathrm{~nm}$. The spectrum of $\left[\mathrm{Co}^{111} \mathrm{~L}^{1}\right]^{+}$shows a Soret band red-shifted relative to the precursor [Co" $\left.\mathrm{C}^{1}\right]$, and has a stronger more narrow $O$ band, at an energy similar to the precursor. ${ }^{18}$ The $\mathrm{Co}^{\mathrm{III}}$ species is almost certainly $\left[\mathrm{Co}^{\mathrm{III}} \mathrm{L}^{1}\right.$ $\left.(\mathrm{OH})_{2}\right]^{-}$, since its electronic spectrum is essentially identical with that of the unsubstituted analogue, $\left[\mathrm{NBu}_{4}\right]\left[\mathrm{Co}^{\mathrm{III}}(\mathrm{pc})\right.$ $\left.(\mathrm{OH})_{2}\right]$, reported previously in chloroform. ${ }^{22}$ Disproportionation takes place when the hydroxide is present in as low as $5: 1$ molar excess to $\left[\mathrm{CoL}^{1}\right]$ and will occur in a range of non-coordinating or weakly co-ordinating solvents such as toluene or dmf, but not in co-ordinating solvents such as pyridine or ethanol wherein the species remain $\left[\mathrm{Co}^{11} \mathrm{~L}^{1}\right]$. Disproportionation is encouraged under conditions where the hydroxide ion can contact the Co atom in an axial site, but is discouraged when solvent occupies the axial sites.

If the disproportionated solution is maintained in an inert

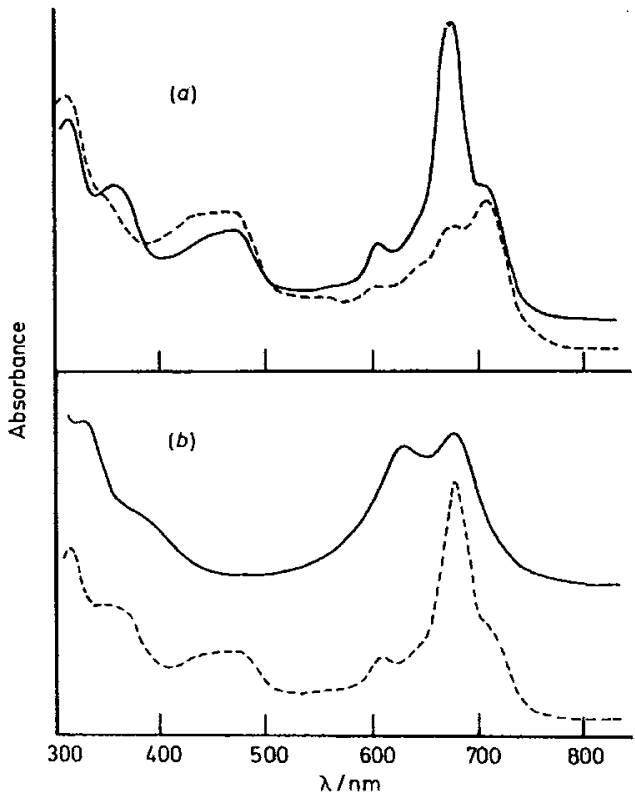

Figure 1. (a) Electronic spectra of disproportionated [CO $\left.\mathrm{CO}^{1} \mathrm{~L}^{\mathrm{i}}\right]^{-}$ $\left[\mathrm{Co}^{1 \mathrm{II}} \mathrm{L}^{1}(\mathrm{OH})_{2}\right]^{-}$mixtures in $\mathrm{C}_{6} \mathrm{H}_{4} \mathrm{Cl}_{2}$ solution (-_- ) and polystyrene film (-- - ) under nitrogen. (b) Electronic spectra of $\left[\mathrm{Co}_{2} \mathrm{~L}^{2}\right]$ in $\mathrm{C}_{6} \mathrm{H}_{4} \mathrm{Cl}_{2}$ solution under nitrogen, before $(\longrightarrow)$ and after (-addition of $160: 1$ molar excess of $\mathrm{NBu}_{4} \mathrm{OH}$ 
Table 1. Electronic absorption maxima ${ }^{a}(\mathrm{~nm})$ of mononuclear $\left[\mathrm{CoL}^{1}\right]$

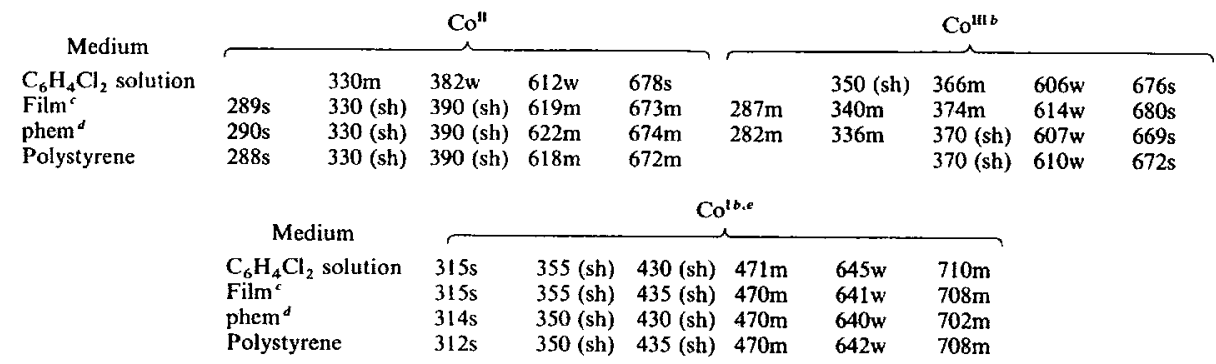

${ }^{a} \mathrm{~s}=$ Strong, $\mathrm{m}=$ medium, $\mathrm{w}=$ weak, $\mathrm{sh}=$ shoulder. ${ }^{b}$ Solutions contain $\mathrm{NBu}_{4} \mathrm{OH}$. ${ }^{c}$ Prepared by evaporation of a toluene solution. ${ }^{4}$ phem $=$ Poly(2-hydroxyethyl methacrylate). ${ }^{*}$ Three additional very weak bands are found between 520 and $600 \mathrm{~nm}$.

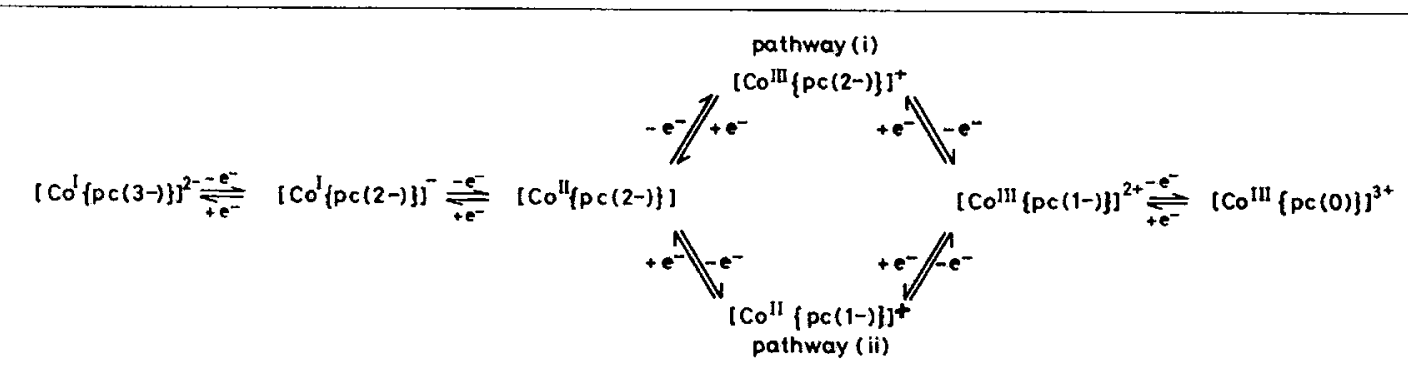

Scheme. Axial ligands are omitted for clarity; $p c=$ phthalocyanine or phthalocyaninate (charge in parentheses)

environment, then slow conversion to $100 \%\left[\mathrm{Co}^{\mathrm{I}} \mathrm{L}^{1}\right]^{-}$occurs, facilitated (rapidly) by light [monochromatic irradiation into the $Q$ band is effective, but with very low $(<0.1 \%)$ quantum yield] [Figure 2(a), Table 1]. Alternatively, if the solution is oxygenated, conversion to $\left[\mathrm{Co}^{\mathrm{III}} \mathrm{L}^{1}(\mathrm{OH})_{2}\right]^{-}$occurs, over a period of minutes [Figure $2(b)$, Table 1].

Similar chemistry may be carried out in dmf with the principal difference that conversion to $\left[\mathrm{Co}^{1} \mathrm{~L}^{2}\right]^{-}$is more facile while conversion to $100 \%\left[\mathrm{Co}^{\mathrm{HH}} \mathrm{L}^{1}(\mathrm{OH})_{2}\right]^{-}$is much more difficult, even in oxygenated solutions, probably due to the presence of reducing species in a $\mathrm{dmf}-\mathrm{OH}^{-}$solution.

Cycling between $\mathrm{Co}^{1}$ and $\mathrm{Co}^{\mathrm{III}}$ can be repeated, but generally with a loss of ca. $10 \%$ on each cycle. During successive cycles of oxidation and reduction, it becomes more difficult to effect reduction of $\left[\mathrm{Co}^{11} \mathrm{~L}^{1}\right]^{+}$to $\left[\mathrm{Co}^{1} \mathrm{~L}^{1}\right]^{-}$(axial ligands omitted), i.e. a longer time is needed. These processes were monitored in cuvettes by electronic spectroscopy; thus only ca. $10^{-6} \mathrm{~mol}$ $\mathrm{dm}^{-3}$ of material was present. It is likely that trace organic material in the solvent, and to some degree the phthalocyanine ring itself, are the reductants in the $\left[\mathrm{Co}^{\mathrm{II}} \mathrm{L}^{1}\right]^{+}$to $\left[\mathrm{Co}^{1} \mathrm{~L}^{1}\right]^{-}$ conversion. Electrochemistry provides a tool to obtain a greater understanding of the disproportionation process.

Electrochemistry in the Presence of Hydroxide Ion-The complex $\left[\mathrm{Co}^{\mathrm{l}}(\mathrm{pc})\right]$ can be oxidised or reduced according to two alternative pathways depending upon solvent or supporting electrolyte ${ }^{1823-25}$ (Scheme)

Pathway (ii) is effective in the absence of a solvent which can co-ordinate axially to the cobalt atom, and in the absence of a strongly axially binding supporting electrolyte anion. When this is not true, pathway (i) is followed. Thus, for example, [CoL $\left.{ }^{1}\right]$ in $\mathrm{C}_{6} \mathrm{H}_{4} \mathrm{Cl}_{2}$ plus a perchlorate supporting electrolyte follows pathway (ii), while dmf or an anion such as chloride facilitate six-co-ordination with $\mathrm{Co}^{\mathrm{III}}$ and favour pathway (i). ${ }^{18}$
In the absence of hydroxide ion, a couple corresponding to the process $\left[\mathrm{Co}^{\Pi} \mathrm{L}^{1}\right]-\left[\mathrm{Co}^{1} \mathrm{~L}^{1}\right]^{-}$(couple $\mathrm{A}$ ) occurs at $-0.91 \mathrm{~V}$ in $\mathrm{C}_{6} \mathrm{H}_{4} \mathrm{Cl}_{2}$ and $-0.85 \mathrm{~V}$ in dmf (vs. ferrocenium-ferrocene). As will be discussed in more detail below, a similar redox couple is retained in the hydroxide ion-containing solutions. Using controlled potential electrolysis either side of this couple, we obtain a greater understanding of the chemistry involved in this process. Thus in the absence of hydroxide ion, controlled potential electrolysis positive and negative of this wave produces the anticipated species $\left[\mathrm{Co}^{i l} \mathrm{~L}^{1}\right]$ and $\left[\mathrm{Co}^{1} \mathrm{~L}^{1}\right]^{-}$ respectively. ${ }^{18}$

Use of an o.t.t.l.e. allows one to monitor the products spectroscopically. If a disproportionated, hydroxide ioncontaining solution is placed in the cell and the gold minigrid polarised ca. $200 \mathrm{mV}$ more positive than couple A, the $470 \mathrm{~nm}$ absorption is lost and the spectrum becomes characteristic of $\left[\mathrm{Co}^{\text {III }} \mathrm{L}^{1}(\mathrm{OH})_{2}\right]^{-}$[Figure 2(b), Table 1]. If the potential is switched $200 \mathrm{mV}$ negative of couple $A$, then re-reduction fully to $\left[\mathrm{Co}^{1} \mathrm{~L}^{1}\right]^{-}$occurs. In neither experiment is any intermediate [Co' $\left.\mathrm{Co}^{1}\right]$ observed.

Such an observation would lead one, initially, to conclude that, in the presence of hydroxide ion, couple $A$ has become a two-electron process. However, as demonstrated below, the potential, waveshape and current of couple $A$ in a $\left[\mathrm{Co}^{1} \mathrm{~L}^{1}\right]^{-}$ bulk solution, containing hydroxide ion, are identical to those in the $\left[\mathrm{Co}^{\prime \prime} \mathrm{L}^{1}\right]$ bulk solution. A two-electron wave should have a peak-to-peak separation of ca. $29 \mathrm{mV},{ }^{26}$ and would be expected to carry twice as much current. Thus we must explain the undoubted two-electron spectroelectrochemistry, yet retain couple $A$ as a one-electron couple associated with the process $\left[\mathrm{Co}^{11} \mathrm{~L}^{1}\right]-\left[\mathrm{Co}^{1} \mathrm{~L}^{1}\right]^{-}$

A dmf solution of $\left[\mathrm{Co}^{11} \mathrm{~L}^{1}\right]$ under nitrogen was investigated electrochemically while titrating it with small quantities of 0.014 $\mathrm{mol} \mathrm{dm^{-3 }} \mathrm{LiOH}-\mathrm{dmf}$. The hydroxide ion-containing solution 


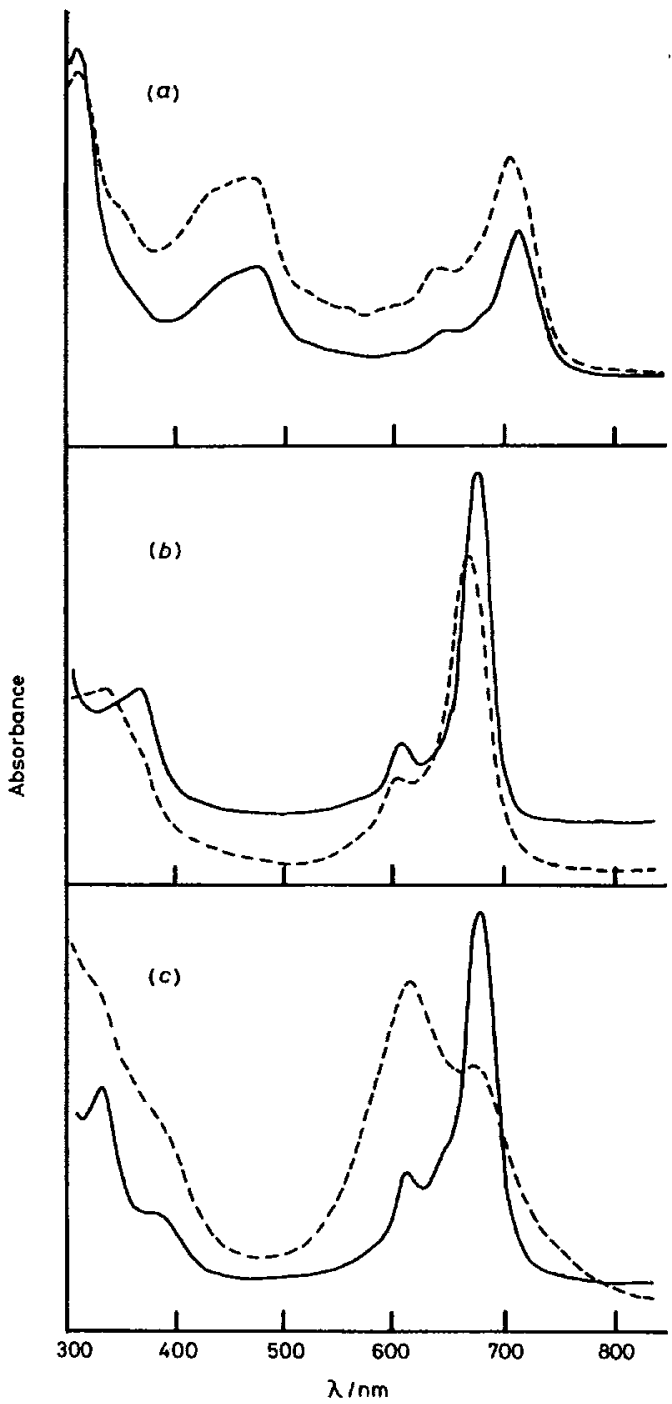

Figure 2. Electronic spectra of $(a)\left[\mathrm{Co}^{1} \mathrm{~L}^{1}\right]^{-},(b)\left[\mathrm{Co}^{\mathrm{II}} \mathrm{L}^{1}(\mathrm{OH})_{2}\right]^{-}$, and (c) $\left[\mathrm{Co}^{11} \mathrm{~L}^{3}\right]$ in $\mathrm{C}_{6} \mathrm{H}_{4} \mathrm{Cl}_{2}$ solution $(-)$ and polystyrene film (c) $\left[\mathrm{Co}^{\mathrm{H}}\right.$

was thoroughly stirred after each addition for $c a .1 \mathrm{~h}$ before recording the data presented in Figure 3. Under such circumstances, any $\left[\mathrm{Co}^{\mathrm{II}_{\mathrm{L}}} \mathrm{L}^{1}(\mathrm{OH})_{2}\right]^{-}$produced is reduced completely to $\left[\mathrm{Co}^{1} \mathrm{~L}^{1}\right]^{-}$, the reductant probably being traces of dimethylamine from solvent decomposition. Figure 3(a) shows two relevant redox couples observed before addition of hydroxide ion. These are: ${ }^{18}\left[\mathrm{Co}^{11} \mathrm{~L}^{1}\right]-\left[\mathrm{Co}^{1} \mathrm{~L}^{1}\right]^{-}$(A) and $\left[\mathrm{Co}^{\mathrm{Ill}} \mathrm{L}^{1}\right]^{+}-\left[\mathrm{Co}^{\mathrm{II}} \mathrm{L}^{1}\right](\mathrm{B})$, where any axial ligands are omitted for clarity. Figure $3(b)$ and $(c)$ reveal the effect upon both the cyclic voltammogram and differential pulse voltammogram as hydroxide ion is added in small molar excess relative to the

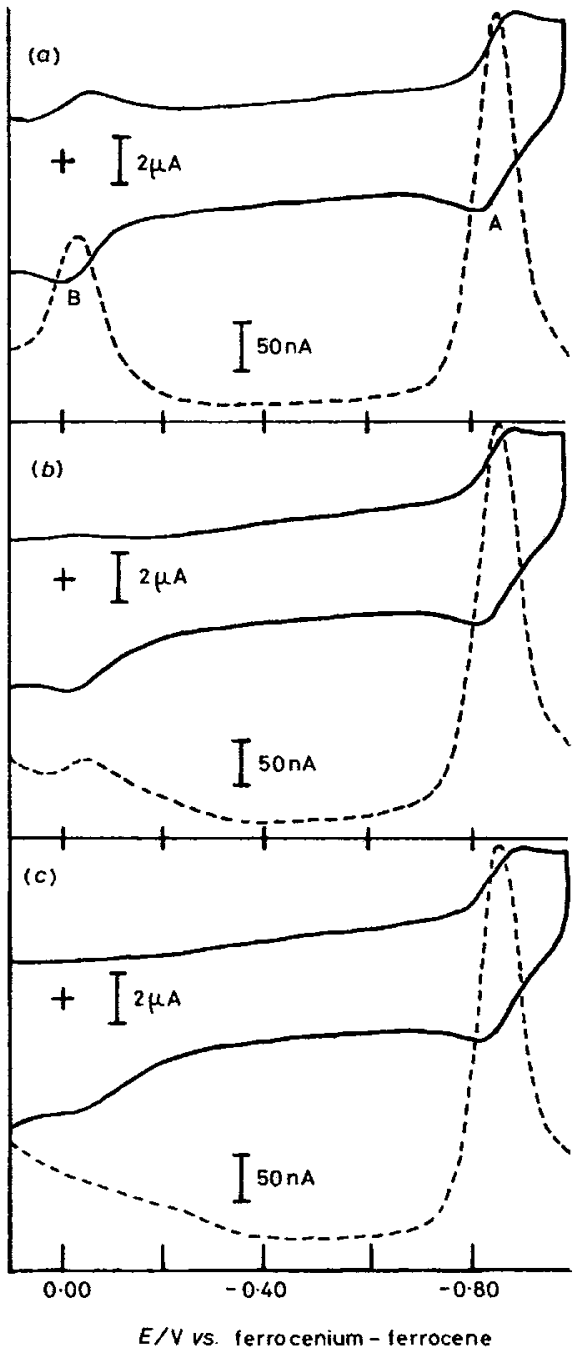

Figure 3. Cyclic voltammetry $(\longrightarrow)$ and differential pulse voltammetry (- - $)$ at a glassy carbon electrode (g.c.e.; area $0.458 \mathrm{~cm}^{2}$ ) of a $9.69 \times 10^{-5} \mathrm{~mol} \mathrm{dm}^{-3}$ solution of $\left[\mathrm{CoL}^{1}\right]$ under nitrogen. The hydroxide ( $\mathrm{LiOH}-\mathrm{dmn}$ ) concentrations in these solutions are $(a) 0,(b)$ $1.4 \times 10^{-4}$, and (c) $2.8 \times 10^{-4} \mathrm{~mol} \mathrm{dm}^{-3}$

solute. It is seen in Figure $3(b)$ that the cathodic portion of couple B is lost as the response becomes irreversible. Figure 3(c) shows that with the further addition of hydroxide, couple B disappears. A 'blank' experiment in the absence of [ $\left.\mathrm{CoL}^{1}\right]$ solute shows that a rising baseline in the differential pulse voltammogram, as observed in Figure $3(c)$, is due to the electrochemical activity of $\mathrm{OH}^{-}$in solution. This limited the electrochemical analysis of this system at high hydroxide concentrations, especially at potentials positive of couple $B$ \{Note that in these $\left[\mathrm{Co}^{1} \mathrm{~L}^{1}\right]^{-}$solutions there is no change in the position, current or appearance of couple A, Figure $3(a)--(c)\}$. 


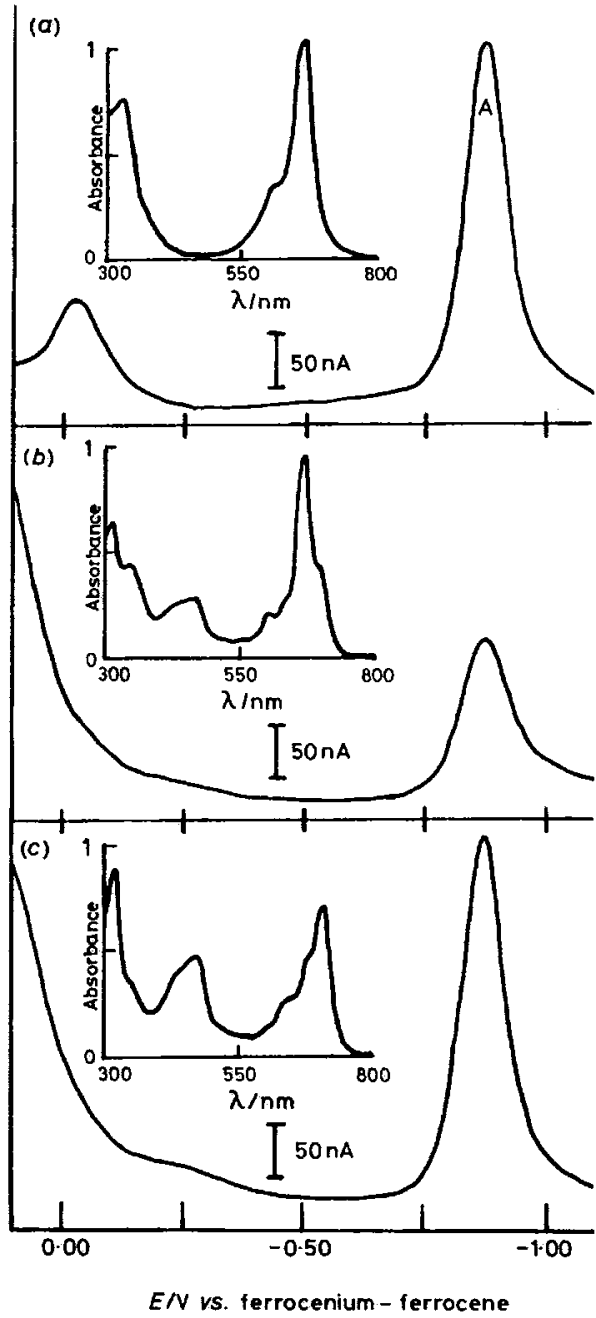

Figure 4. Electronic spectra (pathlength $0.1 \mathrm{~cm}$ ) and differential pulse voltammetry (g.c.e.; area $0.458 \mathrm{~cm}^{2}$ ) of a $1.01 \times 10^{-4} \mathrm{~mol} \mathrm{dm}^{-3}$ solution of $\left[\mathrm{CoL}^{1}\right]$ under oxygen. The hydroxide concentrations $\left(\mathrm{NBu}_{4} \mathrm{OH}-\right.$ $\mathrm{MeOH})$ in these solutions are $(a) 0,(b) 5.0 \times 10^{-4}$ (recorded $30 \mathrm{~min}$ after mixing), and (c) $5.0 \times 10^{-4} \mathrm{~mol} \mathrm{dm}^{-3}$ (recorded $2.5 \mathrm{~h}$ later)

Figure 4 shows the results of an experiment in which sufficient $1 \mathrm{~mol} \mathrm{dm}{ }^{-3} \mathrm{NBu}_{4} \mathrm{OH}$ was added to a dmf solution of $\left[\mathrm{Co}^{11} \mathrm{~L}^{1}\right]$ under nitrogen to give a totally disproportionated solution, but data were collected before there was time for reduction of $\left[\mathrm{Co}^{\mathrm{III}} \mathrm{L}^{1}(\mathrm{OH})_{2}\right]^{-}$to occur. Here we follow the electronic spectra in concert with the electrochemical data. Figure 4(a) gives the electronic spectrum and differential pulse voltammogram of the initial $\left[\mathrm{Co}^{\mathrm{i}} \mathrm{L}^{1}\right]$ solution. The differential pulse voltammogram of the fully disproportionated solution, given with its electronic spectrum in Figure $4(b)$, shows no couple B and reduced peak height for couple $A$. The reduction in current is exactly related to the amount of $\left[\mathrm{Co}^{\mathrm{III}} \mathrm{L}^{1}(\mathrm{OH})_{2}\right]^{-}$species in solution, measured from the relative peak heights of the $680 \mathrm{~nm} \mathrm{Co}{ }^{\text {III }}$ and $470 \mathrm{~nm}$ $\mathrm{Co}^{1}$ electronic absorptions, revealing that a pure $\left[\mathrm{Co}^{I I} \mathrm{~L}^{1}\right.$ $\left.(\mathrm{OH})_{2}\right]^{-}$solution would not exhibit couple A. As the solution was maintained under nitrogen, it slowly converted to $\mathrm{Co}^{1}$ with the quantitative recovery of couple $A$, as seen in Figure $4(c)$.

The above observations may be explained in terms of a specific model in which hydroxide ion does not bind either to $\left[\mathrm{Co}^{11} \mathrm{~L}^{1}\right]$ or $\left[\mathrm{Co}^{1} \mathrm{~L}^{1}\right]^{-}$, but does bind very strongly to $\left[\mathrm{Co}^{111} \mathrm{~L}^{1}\right]^{+}$. Under such circumstances, the potential of the $\mathrm{Co}^{11}-\mathrm{Co}^{\mathrm{I}}$ couple would be unaffected by hydroxide ion, as observed.

The Co ${ }^{\text {III-Coll }}$ couple B becomes irreversible, before it disappears, with loss of cathodic current relative to the anodic current. In the absence of hydroxide ion, couple $B$ corresponds to $\left[\mathrm{Co}^{11 \prime} \mathrm{L}^{1}(\mathrm{dmf})\left(\mathrm{ClO}_{4}\right)\right]-\left[\mathrm{Co}^{\prime \prime} \mathrm{L}^{1}(\mathrm{dmf})\left(\mathrm{ClO}_{4}\right)\right]^{-18}$ As hydroxide titration proceeds, some $\left[\mathrm{Co}^{11} \mathrm{~L}^{1}(\mathrm{dmf})\left(\mathrm{ClO}_{4}\right)\right]^{-}$is oxidised (at couple B) to $\left[\mathrm{Co}^{\mathrm{III}} \mathrm{L}^{1}(\mathrm{OH})_{2}\right]^{-}$which is so stable that it is not reducible at a potential near that of couple $B$, and thus cathodic current is lost [Figure $3(b)$ ].

Since hydroxide ion does not bind $\left[\mathrm{Co}^{\mathrm{II}} \mathrm{L}^{1}\right]$, we now become interested in the potential of the couple represented by equation (1); this may be derived from equations (2) and (3). Process (3)

$$
\begin{aligned}
& {\left[\mathrm{Co}^{\mathrm{III}} \mathrm{L}^{1}(\mathrm{OH})_{2}\right]^{-}+\mathrm{dmf}+\mathrm{ClO}_{4}^{-}+\mathrm{e}^{-\stackrel{E_{2}(1)}{\rightleftharpoons}}} \\
& 2 \mathrm{OH}^{-}+\left[\mathrm{Co}^{\mathrm{II}} \mathrm{L}^{1}(\mathrm{dmf})\left(\mathrm{ClO}_{4}\right)\right]^{-} \\
& {\left[\mathrm{Co}^{\mathrm{III}} \mathrm{L}^{1}(\mathrm{OH})_{2}\right]^{-}+\mathrm{dmf}+\mathrm{ClO}_{4}^{-} \stackrel{K(2)}{\rightleftharpoons}} \\
& 2 \mathrm{OH}^{-}+\left[\mathrm{Co}^{\mathrm{HI}} \mathrm{L}^{1}(\mathrm{dmf})\left(\mathrm{ClO}_{4}\right)\right] \\
& {\left[\mathrm{Co}^{\mathrm{III}} \mathrm{L}^{1}(\mathrm{dmf})\left(\mathrm{ClO}_{4}\right)\right]+\mathrm{e}^{-\stackrel{E_{4}(3)}{\longleftarrow}}} \\
& {\left[\mathrm{Co}^{11} \mathrm{~L}^{\mathrm{t}}(\mathrm{dmn})\left(\mathrm{ClO}_{4}\right)\right]^{-}}
\end{aligned}
$$

corresponds directly with couple $B$, in the absence of hydroxide ion; thus its potential is known. ${ }^{18}$ Process (2) is very unfavourable, given the high affinity for hydroxide ion of $\mathrm{Co}^{\text {IIt }}$ species. ${ }^{27}$

The potential for process (1) may be written as in equation (4) ${ }^{26}$ where $n=$ the number of electrons per pc ring transferred in the redox process and where the last term on the right hand

$$
\begin{aligned}
E_{\mathrm{q}}(1)=E_{\ddagger}(3)+(R T / n F) \ln K(2)- & 2(R T / n F) \ln \left[\mathrm{OH}^{-}\right]+ \\
& (R T / 2 n F) \ln \left(D_{\mathrm{f}} / D_{\mathrm{i}}\right)
\end{aligned}
$$

side is related to the ratio of the diffusion coefficients of the initial (i) and final (f) products in equilibrium (2), and can safely be discarded. Thus equation (4) may be abbreviated to give equations $(5 \mathrm{a})$ and $(5 \mathrm{~b})$.

$$
\begin{gathered}
E_{\frac{1}{2}}(1)=E_{\frac{1}{2}}(3)+(R T / n F)\left\{\ln K(2)-2 \ln \left[\mathrm{OH}^{-}\right]\right\} \\
E_{\frac{1}{2}}(1)-E_{\frac{1}{2}}(3)=0.059\left\{\log K(2)-2 \log \left[\mathrm{OH}^{-}\right]\right\}
\end{gathered}
$$

To explain the observed behaviour, the value of $E_{t}(1)$ must be more negative than the potential of couple $A$, since, under such circumstances, disproportionation will be thermodynamically 'downhill'. Thus a shift of at least $0.9 \mathrm{~V}$ must occur, i.e. the right hand term in equation ( $5 \mathrm{~b})$ must be at least $-0.9 \mathrm{~V}$. Figure 5 shows a plot of equation (5b) in the form of the range of $\left[\mathrm{OH}^{-}\right]$during the experiment against the shift in potential. If $K(2)$ is smaller than ca. $1 \times 10^{-23}$ then the necessary shift will occur, and the shift will exceed $0.9 \mathrm{~V}$ after the first addition of

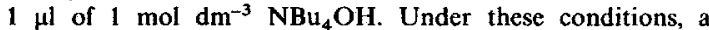
continuous shift in the $\mathrm{Co}^{\text {III-Co }} \mathrm{Co}^{\text {II }}$ potential would not be observed; instead it would diminish in height and disappear, as observed. Thus the experimental data can be explained subject to the value of the equilibrium constant as indicated. Such a small value is not unreasonable since the dihydroxide is likely to be very stable.

It is necessary to explain the absence of couple $A$ in a pure solution of $\left[\mathrm{Co}^{\mathrm{II}} \mathrm{L}^{1}(\mathrm{OH})_{2}\right]^{-}$, and its presence unchanged in the $\left[\mathrm{Co}^{1} \mathrm{~L}^{1}\right]^{-}$solution. In the former case we should not expect to 
see couple A since the $\left[\mathrm{Co}^{\mathrm{In}} \mathrm{L}^{1}(\mathrm{OH})_{2}\right]^{-}$bulk species would not reduce in the region of couple $B$, but at a potential more negative. It would also be irreversible. Because of problems related to background solvent/hydroxide current, it was not possible to observe this wave at potentials negative of couple $A$.

When the cobalt(I) hydroxide ion-containing solution is oxidised at couple $A,\left[\mathrm{Co}^{\mathrm{n}} \mathrm{L}^{1}\right]$ is initially formed. The potential at which this occurs will be the same as for bulk [CoII $\mathrm{L}^{1}$ ] if disproportionation is slow relative to the electrochemical timescale. Indeed disproportionation is slow (minutes) where the molar ratio $\mathrm{OH}:\left[\mathrm{CoL}^{1}\right]$ is low $(\mathrm{ca} .5-20: 1)$ but it is equally true that we are dealing with a very slow time-scale in the differential pulse experiment. An alternative explanation may be that disproportionation cannot occur, for mechanistic reasons, on the electrode, but only occurs after the $\left[\mathrm{Co}^{\mathrm{II}} \mathrm{L}^{1}\right]$ formed at the electrode diffuses away.

A hydroxide-induced reduction of $(5,10,15,20$-tetraphenylporphyrinato)iron(HI), $\left[\mathrm{Fe}^{\mathrm{III}}(\mathrm{tpp})\right]^{+}$, in pyridine to an iron(II) species has recently been reported ${ }^{28}$ but the mechanism is quite different. These workers demonstrated a negative shift of $0.5 \mathrm{~V}$ in the $\mathrm{Fe}^{\mathrm{III}}-\mathrm{Fe}^{\mathrm{Il}}$ potential when hydroxide ion was added to a $\mathrm{Me}_{2} \mathrm{SO}$ solution of $\left[\mathrm{Fe}^{\mathrm{III}}(\mathrm{tpp})\right]^{+}$, but in this case the $\mathrm{Fe}^{\mathrm{II}}-\mathrm{Fe}^{1}$ couple still lies to lower potentials.

Binuclear[Tri(neopentoxy)phthalocyaninato] cobalt Species.Since disproportionation has the potential to generate twoelectron catalysts with mononuclear $\left[\mathrm{CoL}^{1}\right]$, there is obviously the possibility of obtaining four-electron catalysts with the binuclear species.

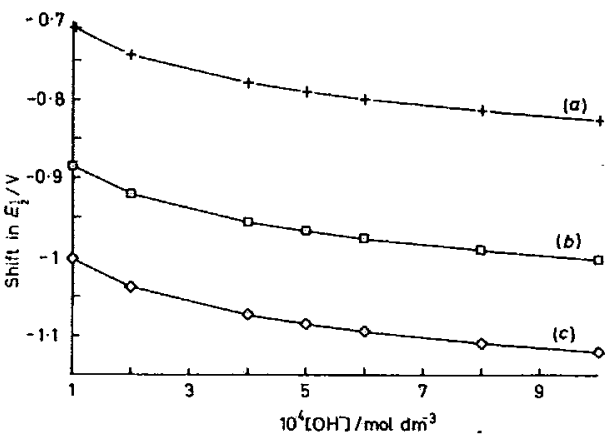

Figure 5. Plot of equation (5b) showing the variation in shift of $E_{\frac{1}{2}}(1)$ as a function of hydroxide concentration and equilibrium constant. $K(2)=10^{-20}(a), 10^{-23}(b)$, and $10^{-25}(c)$, respectively
The electrochemical data for the binuclear derivatives are discussed elsewhere. ${ }^{18} \mathrm{~A}$ series of one-electron redox processes are observed which directly parallel those of the mononuclear species at essentially the same potentials. At least for those systems reported so far, the coupling between the halves of the molecule is evidently not important enough to cause a marked change in these potentials and the molecule behaves electrochemically as two uncoupled mononuclear species. The $\left[\mathrm{Co}_{2} \mathrm{~L}^{2}\right]$ and $\left[\mathrm{Co}_{2} \mathrm{~L}^{3}\right]$ species also behave as mononuclear species electrochemically, implying that cofacial conformations uncouple prior to electrochemical reduction-oxidation.

The addition of excess hydroxide ion $\left(\mathrm{NBu}_{4} \mathrm{OH}, 160: 1\right.$ molar excess) to the $\left[\mathrm{Co}^{11}{ }_{2} \mathrm{~L}^{n}\right](n=2-5)$ species in $\mathrm{C}_{6} \mathrm{H}_{4} \mathrm{Cl}_{2}$ also promotes rapid disproportionation to a $1: 1$ mixture of binuclear $\left[\mathrm{Co}_{2}^{1} \mathrm{~L}^{n}\right]^{2-}$ and binuclear $\left[\mathrm{Co}^{\mathrm{in}}{ }_{2} \mathrm{~L}^{n}(\mathrm{OH})_{4}\right]^{2-}$ species [Figure $1(b)]$. Degassing or irradiation in vacuo provides total conversion to the binuclear $\left[\mathrm{Co}_{2}^{1} \mathrm{~L}^{n}\right]^{2-}$ species, while air oxidation yields the fully oxidised binuclear $\left[\mathrm{Co}^{\text {III }}{ }_{2} \mathrm{~L}^{n}(\mathrm{OH})_{4}\right]^{2-}$ species ('Table 2). Note that direct photoreduction of $\left[\mathrm{Co}^{\mathrm{m}} \mathrm{L}^{1}\right]^{+}$ to $\left[\mathrm{Co}^{\prime} \mathrm{L}^{1}\right]^{-}$(axial ligands omitted) constitutes, in effect, a twoelectron photoreduction, an extremely rare if not unique observation.

Close inspection of the spectrum of the $1: 1$ mixed disproportionation product shows it to be a superimposition of the spectrum of the pure binuclear $\left[\mathrm{Co}_{2}^{1} \mathrm{~L}^{n}\right]^{2-}$ species and the pure binuclear $\left[\mathrm{Co}^{\mathrm{II}}{ }_{2} \mathrm{~L}^{n}(\mathrm{OH})_{4}\right]^{2-}$ species, with no evidence for any additional transitions such as mixed-valence transitions, and no shifting of any internal phthalocyanine transitions. It therefore appears that disproportionation of the binuclear species does not yield a mixed-valence $\left[\mathrm{Co}^{\mathrm{l}} \mathrm{Co}^{\mathrm{II}} \mathrm{L}^{n}\right]$ species.

Chemistry of $\left[\mathrm{Co}^{1} \mathrm{~L}^{1}\right]^{-}$and $\left[\mathrm{Co}^{\mathrm{II}} \mathrm{L}^{1}\right]^{+}$Species.-Obviously one may add specific oxidising or reducing reagents to a solution of $\left[\mathrm{Co}^{1} \mathrm{~L}^{1}\right]^{-}$or $\left[\mathrm{Co}^{111} \mathrm{~L}^{1}\right]^{+}$. Some very preliminary experiments were carried out to seek potentially useful redox processes. For example, the addition of ascorbic acid to a $\left[\mathrm{Co}^{\mathrm{II}} \mathrm{L}^{1}\right]^{+}$solution resulted in formation of $\left[\mathrm{Co}^{1} \mathrm{~L}^{1}\right]^{-}$unless the ascorbic acid is in sufficient excess to neutralise the hydroxide content of the solution, when the final product is [Co" $\left.\mathrm{C}^{1}\right]$.

Transparent films of mononuclear [CoL'] and binuclear $\left[\mathrm{Co}_{2} \mathrm{~L}^{n}\right] \quad(n=2-5)$ species, either pure, or supported in polystyrene or phem, were also briefly studied. Rapid investigation of the chemistry of these films was obtained by following changes in transmittance electronic spectra. Preparation of the films from disproportionated solutions in air yielded $\left[\mathrm{Co}^{11} \mathrm{~L}^{1}(\mathrm{OH})_{2}\right]^{-}$[Figure 2(b). Table 1], while production in vacuo gave mixtures of $\left[\mathrm{Co}^{1} \mathrm{~L}^{1}\right]^{-}$and $\left[\mathrm{Co}^{\mathrm{HI}} \mathrm{L}^{1}\right]^{+}$[Figure $\left.1(a)\right]$.

Films containing $\left[\mathrm{Co}^{\mathrm{III}} \mathrm{L}^{1}\right]^{+}$, or $\mathrm{Co}^{1}-\mathrm{Co}^{\mathrm{m}}$ mixtures, could be

Tahle 2. Electronic absorption maxima ${ }^{a}(\mathrm{~nm})$ of binuclear $\left[\mathrm{Co}_{2} \mathrm{~L}^{n}\right](n=2-5)$ species in $\mathrm{C}_{6} \mathrm{H}_{4} \mathrm{Cl}_{2}$ solution

\begin{tabular}{|c|c|c|c|c|c|c|c|}
\hline \multirow[b]{2}{*}{$\begin{array}{l}\text { Complex } \\
{\left[\mathrm{Co}_{2} \mathbf{L}^{2}\right]} \\
{\left[\mathrm{Co}_{2} \mathbf{L}^{3}\right]} \\
{\left[\mathrm{Co}_{2} \mathbf{L}^{4}\right]} \\
{\left[\mathrm{CO}_{2} \mathbf{L}^{5}\right]}\end{array}$} & \multicolumn{4}{|c|}{$\mathrm{Co}^{\prime \prime}$} & \multicolumn{3}{|c|}{$\mathrm{Co}^{\mathrm{IIt}}$} \\
\hline & $\begin{array}{l}322 \mathrm{~s} \\
330 \mathrm{~m} \\
334 \mathrm{~s} \\
334 \mathrm{~m}\end{array}$ & $\begin{array}{l}380(\mathrm{sh}) \\
380(\mathrm{sh}) \\
380(\mathrm{sh}) \\
380(\mathrm{sh})\end{array}$ & $\begin{array}{l}626 \mathrm{~m} \\
630 \mathrm{~m} \\
628 \mathrm{~m} \\
640 \mathrm{~m}\end{array}$ & $\begin{array}{l}674 \mathrm{~s} \\
680 \mathrm{~s} \\
682 \mathrm{~s} \\
681 \mathrm{~s}\end{array}$ & $\begin{array}{l}360 \mathrm{~m} \\
346 \mathrm{~m} \\
340 \mathrm{~m} \\
349 \mathrm{w}\end{array}$ & $\begin{array}{l}610 w \\
608 w \\
610 \mathrm{~m} \\
613 w\end{array}$ & $\begin{array}{l}675 \mathrm{~s} \\
675 \mathrm{~s} \\
678 \mathrm{~s} \\
679 \mathrm{~s}\end{array}$ \\
\hline Complex & & & & $\mathrm{Co}^{\prime}$ & & & \\
\hline $\begin{array}{l}{\left[\mathrm{Co}_{2} \mathbf{L}^{2}\right]} \\
{\left[\mathrm{Co}_{2} \mathbf{L}^{3}\right]} \\
{\left[\mathrm{Co}_{2} \mathbf{L}^{4}\right]} \\
{\left[\mathrm{Co}_{2} \mathbf{L}^{5}\right]}\end{array}$ & $\begin{array}{l}317 \mathrm{~s} \\
317 \mathrm{~s} \\
315 \mathrm{~s} \\
317 \mathrm{~s}\end{array}$ & $\begin{array}{l}355(\mathrm{sh}) \\
350(\mathrm{sh}) \\
350(\mathrm{sh}) \\
350(\mathrm{sh})\end{array}$ & $\begin{array}{l}430(\mathrm{sh}) \\
435(\mathrm{sh}) \\
430(\mathrm{sh}) \\
430(\mathrm{sh})\end{array}$ & $\begin{array}{l}474 \mathrm{~m} \\
473 \mathrm{~m} \\
473 \mathrm{~m} \\
474 \mathrm{~m}\end{array}$ & $\begin{array}{l}586 w \\
584 w\end{array}$ & $\begin{array}{l}642(\mathrm{sh}) \\
642 \mathrm{w} \\
640 \mathrm{w} \\
642 \mathrm{w}\end{array}$ & $\begin{array}{l}709 \mathrm{~m} \\
708 \mathrm{~m} \\
710 \mathrm{~m} \\
710 \mathrm{~m}\end{array}$ \\
\hline
\end{tabular}

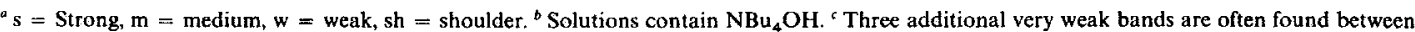
520 and $600 \mathrm{~nm}$. 
converted completely to $\left[\mathrm{Co}^{1} \mathrm{~L}^{1}\right]^{-}$by irradiation for a few minutes in vacuo [Figure 2(a), Table 1]. Heating the [Co' $\left.{ }^{\text {III }} \mathrm{L}^{1}\right]$ film in air (or in vacuo) also generated $\left[\mathrm{Co}^{l} \mathrm{~L}^{1}\right]^{-}$, perhaps because the higher temperature facilitates oxidative decomposition of the polymer. In this case, cooling the film back to roon temperature restored $\left[\mathrm{Co}^{\mathrm{Ht}} \mathrm{L}^{1}\right]^{+}$. As in solution, cycling did not fully reproduce the original quantity of phthalocyanine material, a loss of some $10 \%$ occurring for each cycle.

The $\left[\mathrm{Co}^{1} \mathrm{~L}^{1}\right]^{-}$films were very stable to oxidation in dry air $\left(>24 \mathrm{~h}\right.$ ) but were fairly rapidly oxidised to $\left[\mathrm{Co}^{\mathrm{H}} \mathrm{L}^{1}\right]$ by moist air or moist oxygen. Addition of degassed water (neutral or basic with $\mathrm{NaOH}$ ) to a [Co $\left.\mathrm{Co}^{1}\right]^{-}$film, in vacuo, yielded no reaction. However, addition of degassed aqueous acid $\left(1 \mathrm{~mol} \mathrm{dm}{ }^{-3} \mathrm{HCl}\right)$ in vacuo, ${ }^{29.30}$ or degassed aqueous $\mathrm{Na}_{2} \mathrm{CO}_{3}-\mathrm{NaOH},{ }^{31.3}$ resulted in formation of $\left[\mathrm{Co}^{11} L^{1}\right]$. There is also a slow reaction with degassed aqueous $\mathrm{Na}_{2} \mathrm{SO}_{3}-\mathrm{NaOH}$ leading to [Co' $\left.\mathrm{Co}^{\prime \prime} \mathrm{L}^{1}\right]$ Thus $\left[\mathrm{Co}^{11} \mathrm{~L}^{1}\right]$ is the end-product of oxidation of $\left[\mathrm{Co}^{1} \mathrm{~L}^{1}\right]^{-}$, by wet oxygen, protons, carbonate or sulphite ion. Nitrite does not react with the species under discussion here, but does react slowly with a tetranuclear [tri(neopentoxy)phthalocyaninato] cobalt species. ${ }^{33}$ That $\left[\mathrm{Co}^{\mathrm{II}} \mathrm{L}^{1}\right]$ and not $\left[\mathrm{Co}^{11} \mathrm{~L}^{1}\right]^{+}$is formed in film medium probably refiects the inability of hydroxide ion to migrate under these conditions.

Addition of perchloric acid to a film of $\left[\mathrm{Co}^{\mathrm{II}} \mathrm{L}^{1}(\mathrm{OH})_{2}\right]^{-}$ neutralises the hydroxide ion and generates a $\left[\mathrm{Co}^{\mathrm{IH}} \mathrm{L}^{1}\right]^{+}$species probably with bound axial water. This is expected ${ }^{24,34}$ to have a standard $\mathrm{Co}^{\mathrm{III}}-\mathrm{Co}^{\text {Il }}$ potential near $0.1-0.5 \mathrm{~V}$ (vs. ferroceniumferrocene). Indeed, reduction to a [Co $\left.{ }^{11} L^{1}\right]$ film occurs spontaneously upon addition of acid. The other products were not investigated except for the fact that no oxygen production could be detected by mass spectroscopy.

The above experiments were carried out to access rapidly the possible redox chemistry of the $\mathrm{Co}^{1}$ and $\mathrm{Co}^{111}$ species. Since no really unusual chemistry associable with co-operative effects was observed in this series, the experiments were suspended without spending the time to determine the other products. The experiments are useful in providing controls for current studies of more highly coupled species.

Electronic Coupling in Solution and in the Solid State.-The function of a multi-electron redox catalyst probably depends both upon geometric and electronic constraints. We there fore consider the extent of cofacial interactions in the $\left[\mathrm{Co}_{2} \mathrm{~L}^{n}\right](n=2-5)$ species and the degree of electronic coupling between each half of these binuclear molecules in thei various oxidation states. Such information can be obtained from consideration of the electronic spectra.

The relevant theory for electronic coupling has recently been presented. ${ }^{5}$ These binuclear species may exist in several conformations in dynamic equilibrium, and the electronic spectrum will be a summation of the spectra of a mixture of conformers (uncoupled, coupled through space, and cofacial coupled). Thus, cofacial conformers will only make a partial contribution to the observed spectrum. Coupling result generally in a blue-shifted $Q$-band absorption. Red-shifted absorption can also be anticipated in lower symmetry species, but the probability (intensity) is smaller than for the blue-shifted transitions. ${ }^{5}$ A broad $Q$-band absorption originating from the red edge of the original $Q$ band, and generally showing two peaks, is observed. The degree of broadening is a qualitative measure of the degree of electronic coupling. The lower energy peak corresponds to conformers with little or no coupling and occurs at the same wavelength as the mononuclear specie (Tables 1 and 2). The higher energy peak corresponds to the dominant conformer and, from previous experience, ${ }^{5.18 .33-40}$ will be seen $c a .500-1500 \mathrm{~cm}^{-1}$ to higher energy.

The broad double-peaked $Q$-band spectrum is observed for both $\left[\mathrm{Co}_{2}^{\mathrm{II}} \mathrm{L}^{2}\right]$ and $\left[\mathrm{Co}_{2}{ }_{2} \mathrm{~L}^{3}\right]$ in non-co-ordinating solvents.
Since both of these binuclear species are believed to be capable of cofacial conformer formation, ${ }^{1.5}$ such absorption is associated with the presence of a significant contribution from cofacial, or closed 'clamshell' conformation(s). ${ }^{\prime}$ Reduction to cobalt(I) generates a broad structured absorption near $475 \mathrm{~nm}$ due to $\mathrm{Co}^{1} \longrightarrow \pi^{*}\left(\mathrm{~L}^{n}\right)$ m.l.c.t. transitions ${ }^{19-21}$ and a single rather than double, $O$ band with associated vibrational structure (Table 2). Phthalocyaninatocobalt(I) species are expected to be four-co-ordinate ${ }^{24}$ and will carry a negative charge causing repulsion between the halves of the binuclear molecule, thereby inhibiting a cofacial conformation. Deprotonated metal-free binuclear tri(neopentoxy)phthalocyaninate derivatives are 'open' for the same reason.'

Similarly, oxidation to $\left[\mathrm{Co}_{2}^{I I} \mathrm{~L}^{n}\right]^{2+}$ derivatives generally yielded only a single $Q$ band (Table 2 ). The normal requirement for cobalt(iil) to be six-co-ordinate ensures the presence of axial ligands, inhibiting formation of the cofacial conformer.

Nevertheless, through-space coupling between the halves of each binuclear molecule is anticipated, in both the $\mathrm{Co}^{\prime}$ and $\mathrm{Co}^{\mathrm{III}}$ species. The coupling, if present, even if insufficient to cause splitting of the $Q$ band, should broaden it. This is reflected in the half-bandwidths for the $Q$ band, which are greater than for the mononuclear molecule and follow the same sequence for both $\mathrm{Co}^{\mathrm{I}}$ and $\mathrm{Co}^{\mathrm{III}}$ respectively [half-bandwidths $\left(\mathrm{cm}^{-1}\right)$ given in parentheses]: $L^{1}(660)<L^{4}(735)<L^{2}(775)=L^{3}(775)<$ $\mathrm{L}^{5}(920) ; \mathrm{L}^{1}(680)<\mathrm{L}^{4}(765)<\mathrm{L}^{2}(785)<\mathrm{L}^{3}(800)<\mathrm{L}^{5}$ (1 080 ).

Whereas in the $\left[\mathrm{Co}_{2} \mathrm{~L}^{4}\right]$ and $\left[\mathrm{Co}_{2} \mathrm{~L}^{2}\right]$ species, the halves of the molecule may rotate to be fairly far apart, steric constraints inhibit this in $\left[\mathrm{Co}_{2} \mathrm{~L}^{3}\right]$ and $\left[\mathrm{Co}_{2} \mathrm{~L}^{5}\right]$. This sequence is therefore reasonable, reflecting increasing coupling in those species where the halves are constrained to be close even if not cofacial.

Aggregation is a well known phenomenon in phthalocyanine chemistry. ${ }^{5,33-38}$ Aggregation will be observed in the solid state for mono- and bi-nuclear [ $\left.\mathrm{Co}^{11} \mathrm{~L}^{1}\right]$ and $\left[\mathrm{Co}_{2}{ }_{2} \mathrm{~L}^{n}\right](n=2-5)$ species, but will be absent, or less pronounced, for both $\mathrm{Co}^{1}$ and $\mathrm{Co}^{\mathrm{JI}}$ derivatives. Hence the electronic spectra of the $\left[\mathrm{Co}^{\mathrm{H}} \mathrm{L}^{\mathrm{t}}\right]$ species, in the $Q$-band region, in pure or polymer films, are markedly different from those in dilute solution. The band at $620 \mathrm{~nm}$ increases in intensity so that it is now comparable to, or more intense than the band at $680 \mathrm{~nm}$ [Figure 2(c), Table 1]. On the other hand, the $Q$-band regions of the spectra of the $\left[\mathrm{Co}^{1} \mathrm{~L}^{1}\right]^{-}$ and $\left[\mathrm{Co}^{111} \mathrm{~L}^{1}\right]^{+}$species in the solid phase are much closer to those of dilute solutions [Figure $2(a)$ and $(b)$, Table 1].

Intermolecular interactions (aggregation) can be monitored by the broadening in the $Q$-band region where it is noted they become more pronounced in the condensed phases \{values of half-bandwidth $\left(\mathrm{cm}^{-1}\right)$ for $\left[\mathrm{Co}^{1} L^{1}\right]^{-}$and $\left[\mathrm{Co}^{\mathrm{III}} \mathrm{L}^{1}\right]^{+}$respectively\}: $\mathrm{C}_{6} \mathrm{H}_{4} \mathrm{Cl}_{2}, 660$ and 680 ; phem, 725 and 920 ; pure film, 800 and 1085 .

The absorbances of the films and solution are all similar, but the optical pathlength through the film is very much shorter than for a solution in a cuvette, thus the relative concentration is much higher $\left([\mathrm{pc}]_{\mathrm{film}}=10^{2}[\mathrm{pc}]_{\text {solution }}\right)$.

\section{Conclusions}

The addition of hydroxide ion causes disproportionation of cobalt phthalocyanines dissolved in non-co-ordinating or weakly co-ordinating solvents. The electrochemical data presented here show that the disproportionation is due to a combination of properties, specifically the large bonding energy in dihydroxycobalt(III) phthalocyanines, and the absence of binding of hydroxide ion by cobalt(u) phthalocyanines Disproportionation provides a simple mechanism to generate species with the potential for involvement in concerted multi- 
electron redox processes. Such studies, with polynuclear species, are underway.

The binuclear species described here show spectroscopic evidence for coupling between the halves of the molecule The experimental redox data do not reflect that coupling to any significant extent. However, even in this series, subtle chemical effects have been seen, specifically increased kinetic currents for oxygen reduction, paralleling the sequence of coupling portrayed above. ${ }^{15}$ This paper provides the 'control' data for a series of redox experiments involving the mononuclear and weakly coupled binuclear species. More strongly coupled species are now available and their properties will be published in due course.

\section{Acknowledgements}

The financial support of the Natural Sciences and Engineering Research Council (Ottawa) and the Office of Naval Research (Washington) is gratefully acknowledged. We are indebted to Mrs. Shafi Greenberg for help with the synthesis of complexes.

\section{References}

I C. C. Leznoff, S. Greenberg, S. M. Marcuccio, P. C. Minor, P. Seymour, A. B. P. Lever, and K. B. Tomer, Inorg. Chim. Acta, 1984, 89, L35; C. C. Leznoff, S. M. Marcuccio, S. Greenberg, A. B. P. Lever, and K. B. Tomer, Can. J. Chem., 1985, 63, 623.

2 S. M. Marcuccio, P. I. Svirskaya, S. Greenberg, A. B. P. Lever, C. C. Leznoff, and K. B. Tomer, Can, J Chem, 1985, 63, 3057.

3 S. Greenberg, S. M. Marcuccio, C. C. Leznoff, and K. B. Tomer, Synthesis, 1986, 406 .

A. B. P. Lever, M. R. Hempstead, C. C. Leznof, W. Liu, M. Melnik, W. A. Nevin, and P. Seymour, Pure Appl. Chem., 1986, 58, 1467.

5 E. S. Dodsworth, A. B. P. Lever, P. Seymour, and C. C. Leznoff, $J$. Phys. Chem. 1985, 89, 5698

6 M. Gouterman, in 'The Porphyrins,' ed. D. Dolphin, Academic Press, New York, 1978, vol. 3, part A, p. 1.

7 J. P. Collman, M. Marrocco, P. Denisevich, C. Koval, and F. C. Anson, J. Electroanal. Chem., 1979, 101, 117.

8 J. P. Collman, P. Denisevich, Y. Konai, M. Marrocco, C. A. Koval, and F. C. Anson, J. Am. Chem. Soc., 1980, 102, 6027; R. R. Durand, jun., C. S. Bencosme, J. P. Collman, and F. C. Anson, ibid., 1983, 105, 2710.

9 R. R. Durand, jun., J. P. Collman, and F. C. Anson, J. Electroanal. Chem., 1983, 151, 289.

10 S. Zecevic, B. Simic-Glavaski, E. Yeager, A. B. P. Lever, and P. C. Minor, J. Electroanal. Chem., 1985, 196, 339.

$11 \mathrm{~N}$. Kobayashi and Y. Nishiyama, J. Phys. Chem., 1985, 89, 1167.

$12 \mathrm{M}$. Savy, P. Andro, C. Bernard, and G. Magner, Electrochim. Acta, $1973,18,191$.

13 A. J. Appleby and M. Savy, Nat. Bur. Stand. Spec. Publ., 1976, p. 455; Electrochim. Acta, 1977, 22, 1315.
14 S. Maroie, M. Savy, and J. J. Verbist, Inorg. Chem., 1979, 18, 2560 A. J. Appleby, J. Fleisch, and M. Savy, J. Catal., 1976, 44, 281.

15 M. R. Hempstead, A. B. P. Lever, and C. C. Leznoff, unpublished work.

16 R. R. Gagne, C. A. Koval, and D. C. Lisensky, Inorg. Chem., 1980, 19, 2854; G. Gritzner and J. Kuta, Electrochim. Acta, 1984, 29, 869.

17 W. A. Nevin and A. B. P. Lever, unpublished work.

18 W. A. Nevin, M. R. Hempstead, W. Liu, C. C. Leznoff, and A. B. P. Lever, Inorg. Chem., 1987, 26, 570.

9 P. C. Minor, M. Gouterman, and A. B. P. Lever, Inorg. Chem., 1985 24, 1894.

20 A. B. P. Lever, S. Licoccia, K. Magnell, P. C. Minor, and B. S Ramaswamy, ACS Symp. Ser., 1982, 201, 237

21 M. J. Stillman and A. J. Thomson, J. Chem. Soc., Faraday Trans. 2, 1974, 805.

22 H. Homborg and W. Kalz, Z. Naturforsch., Teil B, 1984, 39, 1490

23 V. I. Gavrilov, N. V. Butusova, E. A. Luk'yanets, and I. V. Shelepin, Sov. Electrochem., 1980, 16, 1321; V. L. Gavrilov, L. G. Tomilova, I. V Shelepin, and E. A. Luk'yanets, ibid., 1979, 15, 914

24 A. B. P. Lever and J. P. Wilshire, Inorg. Chem, 1978, 17, 1145; Can.J. Chem., 1976, 54, 2514.

25 J. F. Myers, G. W. Rayner-Canham, and A. B. P. Lever, Inorg-Chem., $1975,14,461$

26 A. J. Bard and L. R. Faulkner, 'Electrochemical Methods: Fundamentals and Applications,' Wiley, New York, 1980.

27 F. A. Cotton and G. Wilkinson, 'Advanced Inorganic Chemistry,' 4th edn., Wiley, New York, 1980.

28 G. S. Srivatsa and D. T. Sawyer, Inorg. Chem., 1985, 24, 1732

29 C. V. Krishnan, C. Creutz, D. Mahajan, H. A. Schwarz, and N. Sutin. Isr. J. Chem., 1982, 22, 98

30 C. V. Krishnan and N. Sutin, J. Am. Chem. Soc., 1981, 103, 2141.

31 C. M. Lieber and N. S. Lewis, J. Am. Chem. Soc., 1984, 106, 5033

32 F. R. Keene, C. Creutz and N. Sutin, Coord. Chem. Rev., 1985, 64, 247.

33 W. A. Nevin, W. Liu, S. Greenberg, M. R. Hempstead, S. M. Marcuccio, M. Melnik, C. C. Leznoff, and A. B. P. Lever, Inorg. Chem., 1987, 26, 891 .

34 W. A. Nevin, W. Liu, M. Melnik, and A. B. P. Lever, J. Electroanal. Chem. 1986, 213, 217.

35 R. D. Farina, D. J. Halko, and J. H. Swinehart, J. Phys. Chem., 1972, 76, 2343.

36 K. Bernauer and S. Fallab, Helv. Chim. Acta, 1961, 44, 1287.

37 A. R. Monahan, J. A. Brado, and A. F. DeLuca, J. Phys. Chem., 1972, 76, 1994.

38 E. W. Abel, J. M. Pratt, and R. Whelan, J. Chem. Soc, Dalton Trans, $1976,509$.

39 M. Gouterman, D. Holten, and E. Lieberman, Chem. Phys., 1977, 25, 139.

40 A. B. Anderson, T. L. Gordon, and M. E. Kenney, J. Am. Chem. Soc., 1985, 107, 192. 